\title{
PHILOSOPHICAL, SOME LEGAL AND POLITICAL ASPECTS OF CONTEMPORARY IDEA OF RESERVE FORCES IN NATO ALLIANCE
}

\author{
Arnold Warchal \\ Military University of Technology
}

\begin{abstract}
The idea of citizen soldiers can be dated to ancient times. Through the process of democratization it has gotten a new grounding, beginning with the evolution of modern states. The author of this article is making a short but general overview of the basic concepts of this evolution, albeit not in a historical perspective. According to the main premise, it is more a philosophy of the state and general political ideas that allow the military to become the highly skilled, democratically controlled force of soldiers and potential citizens soldiers through the system of national reserves. The force of the reservist based on NATO's philosophy and strategic concepts is supposed strengthen the regular conscripts and make a liaison with the socio-political civilian sphere of the particular nations. This concept, as is shown, applies to many countries of the Euro-Atlantic community of states, including Poland. Their common denominator lies in the republican idea of democracy and the individual citizens' responsibility for its nation.
\end{abstract}

The contemporary idea of national reserve forces is grounded in many aspects of socio-political and economic life of the State. It coincides with patriotic participation within security interests of a country, military training and service, and political and legal rules. The main prerogatives of this approach, as it is usually stressed, have to do with domestic military assignments both in time of peace and time of crisis, performed by the citizens with an excellent military training but most of the time not kept under arms. Consequently it is also measured to be a preparation for potential conflict, additional force of militarily trained men for any goals of the armed forces, as well as a steady adjustment of the military to changing international political environment.

This philosophy of political and military strategic concept of defense and preparedness for war can be traced way back into history of many nations throughout the world. However, when we discuss the systematic army readjustment within a modern state, particularly considered in the euro-atlantic political context, we can trace its roots to the number of historical European events, such as the creation of the American Republic and Napoleonic wars. Its first systematic arrangement is already visible with the Prussian reevaluation of its loses and constrains put on 
Prussia (limiting its army size) by the French, after the defeat at the battle of Jenna. The answer to those limits was creation of the, so called krumpersystem ${ }^{1}$.

Examining contemporary effects of the basic idea of territorial integrity protection by a state, taking also into account its other political goals, we can consider reserve system design as being twofold. First of all, it stems out of necessity of territorial protection with provisions for the internal order, including socio-economic aspects and general wellbeing of its population. And secondly, coinciding or at least being parallel to the first, it is based on voluntary acceptance of citizenry as the fundamental grounding of its political and legal actions in different aspects of government's behavior. This adapts the state to the special and temporal conditions on a larger scale, specifically to a given international order, where it must meet the specific prerogatives towards own security goals. We can see in this approach positivistic influence of legal and bureaucratic theories dating back to the XIX century, exemplified, among the others, by Georg Jellinek's "three dimensional theory of state", Max Weber's theory of the state and bureaucracy, plus other continental theorists of legal studies and politics. However, whatever the theoretical approach, it should be understood as a general tendency of adapting the general rules for government's practical solutions into the political and legal language, keeping in mind rationality of many variations of that type in security studies, legal studies and political science.

On the second part of that design one can really philosophize, since it can be historical and anthropological in nature. Since ancient times, many philosophers and social scientists, when talking of human nature dwell on visions of security and harmony for the members of community and the individual members thereof. It would be pointless to present those ideas since we notice them in the speeches of politicians and warriors, like Pericles or Cyrus II the Great, philosophers like Socrates, Plato and Aristotle, and many others since. When we look into its historical and anthropological contexts and examples of many countries presenting complex social behaviors and stands, there can be observed patriotic involvement of the members of a given society, with respect to defense of their families and community in a time of war, social upheaval or natural disasters. This seems to be true of every community's natural response to any kind of danger when quickly called to service militia or other working military and nonmilitary groups can diminish its consequences. And this is true of any society and any political system, both in contemporary, modern and ancient times.

In democracy this basic call for security is usually a result of political project. It is influenced by imposing on the members of political society freedom of taking care of their own affairs on one hand, and responsibility for their own being, on the other. No doubt this line of thought is present throughout NATO alliance. It was for example also implied by General Harald Kujat, in 2003 Chairman of the NATO

1 www.brittanica.com/EBchecked/topic/323910/Krumpersystem. 
Philosophical, some legal and political aspects of contemporary idea of reserve forces...

Military Committee (in his speech on 25 July 2003) who said that “...in most of our nations, reservists provided the necessary backbone elements of their country's march on the path to nationhood. Reserves hold indeed a place of choice in our respective societies"2. The general also cited professor of history and classics at Cornell's University, Barry Strauss, who said: “...political theory teaches that, unless the citizens of a republic serve in their own defense, they risk losing their freedom"3.

In contemporary states that have evolved through parliamentary process into fully pledged democracy we can additionally see this idea's fuller evolution. It is common especially in the Euro-Atlantic community of the states, but in other countries can be true as well. Probably one of the oldest examples of that sort can be historically connected to the moment of the raise of the Persian empire, parallel to the rise of the first European democracy in Athens, when the soon to become Persian king Cyrus II the Great in the VIth century BC called the lower casts of society to arms giving them fuller freedoms, on the bases that they accept the burden of responsibility for their country. Not long after his famous speech, the army of Cyrus controlled Persia and large portions of the Middle East. Entire process of Cyrus's political behavior can be viewed as proto-republicanism. Since that time we can find other examples of that sort.

Based on a republican initiative of citizen's control of different aspects of its political behavior it was implicit that a "call to arms" is also a political decision, taken up by the monarchs, or by the members of society themselves, or by their representatives. From this point there is a short way to the full conceptualization of democratic ideas. In many books dealing with contemporary democracies, we can understand a country to be democratic only when it includes in its political behavior, as one of the major criteria's of republican democracy, prospects for the citizens' representatives to create different mechanisms for civil control of the armed forces through the legislative, judicial and executive order of constitutionally based values. Some of the best evolved major democracies of the world can exemplify this process to-day: United States and its militia evolving into particular state controlled Army National Guard and other reservist, or Switzerland and military training and readiness of citizens, who are allowed to keep at home state issued arms for potential mobilization.

We can take upon many different points of departure for security, however it seems that the core of its subject studies, withholding technical and specific military specializations problems, will directly or indirectly refer to the state and its citizens, or population as a whole regardless of its political status. This especially today is of the innermost importance for potential security questions and studies we might approach. In the explanatory processes given and based on the above presumptions, we can notice

2 Gen. H. Kujat, The Use of Reservists within NATO, Remarks by General Harald Kujat: http://www. nato.int/ims/2003/s030723e.htm

3 B. Strauss, Reflections on the citizen-soldier, Parameters, U.S. War College, 2003, p. 66. 
different inclusions of that sort. It will surely, at least in general terms, influence the methodology of many unambiguous concerns that may justly focus on particular topics of interests looking through political values and because of it creating many specific, both deductively and inductively gathered explanations, as it is done in this case.

Human security in recent times, as well as in the past, depends on the harmonious co-existence of the state within the international scene influenced by common political and economic details. This is true of the European countries at least since the "Concert of Vienna" of 1815, when drafters of the multilateral agreement for the post-Napoleonic European order created a modern international system. At the same moment the new architecture of state and its security was drafted and put into practice. It should be understood however as a part of wider evolution that surely was based also on other values preceding the return of aristocratic vision of international order. Perhaps it was only one side of the same coin, where those other values were influenced by the idea of a "social contract" envisioned by the thinkers of the previous century living and writing in the age of Enlightenment.

Looking at history of this evolution of state and contemporary international security issues we know that any perspective can be widened to other examples. Observed through any historical spectrum, the issue of national security will depend on many factors, but its main common denominator will have to do with the acceptance of a specified political fundament. As it is well known, political fundaments are usually, even if not always created by historical processes of multidimensional proportions coinciding with the many subjects of social sciences. This neither diminishes exponential specialized terminology of specific military studies or the role of the specialists who tend to look into security process in more focused and narrower perspective than social scientists.

Outside of military studies, where experts of the field can often agree when it comes to a given practical and pragmatic concerns and can be objectified, albeit not always, the statements on security of the state can vary because of both subjective and objective grounding. However in the realms of social sciences we usually find mixed topics that describe given areas of social involvement of many subjects that rationalize citizen's feeling of well being, personal safety and general security. Its aim is in many aspects simplified to possible conclusion that personal safety and general security allows society to establish its productive course of development. What follows is the allocation in the state the authority to become full pledged player at the "game" of international interactions. That interaction in present times refers to legal ability of participating within the United Nations system with many other states of different culture and political arrangements.

Considering in that perspective democracy as the ideally taken point of departure for a discussion on security concepts, one of its premises will have to include the constitutional general values and specific solutions found on its pages. The other 
Philosophical, some legal and political aspects of contemporary idea of reserve forces...

premises, corresponding to constitutional concern, will have to deal with the issue of law and lawful actions within the sphere of security. Still others should concentrate on state's population, an issue overlapping with number of persons in military and state security forces. However, whatever assertion are verbalized we can't not exclude the importance of the individual human being, finding in its value logical connection of many diverse predicaments that have to be dealt with withing a cognitive process. Democracy is mainly interested in a political system with its members. It does not treat the individual member only as a value in itself, however, it sees that member as a building block and a defender of that value.

Society depends on its members on many levels of its life and security is probably the most important aspect of personal existence in present time democracies. Since current political situation is coinciding with economic dominating paradigm of capitalism throughout the world the security issues have to be adapted accordingly. There is well observed in the past as well as in a recent history of the state a particular unison between the issues of security and political system. We can notice that a given combination of those political factors either creates the interpretative paradigm or strongly influences the major premises it poses. Needless to say, political system directly influences the way armed forces are controlled and operate based on directives of the state's administration, executive, judiciary and legislative branches. Perhaps it will not be an overstated when we add to those administrative issues economic factor, with suggestion that it probably plays in democratic systems much more important role than in other systems.

Summarizing the above, in general practice of the armed forces, withholding the exceptions, it is the state in its different representations throughout the world that usually controls given aspects of armed forces actions. The administrative control coincides with social and political goals of a given country. Armed forces therefore become politicized when it comes to goal creation for its actions in the missions of military and nonmilitary threats of domestic, intra and international missions. This implies that in democratic countries the most important role of the state is to provide security for its citizens, and this role is not limited by no means to the military conflict only and of course is not limited to the use of its armed forces. Actually, one can define today a whole array of present and potential dangers where the role of armed forces is either limited or not necessary at all. However, when it comes to security it is always the states' and citizens' responsibility. When it comes to the agenda and security strategies the greater burden still lies in the area of state's focus and military specialists, but without educated citizens this may not be enough for coping with contemporary problems.

It is true that for many democracies there is no present danger of full scale wars of the internal and external cause. When it comes to international process, for the moment before the attack at the World Trade Center of 9/11, it seemed that the world 
was becoming a more peaceful place slowly evolving into "the global village". This idea had to be quickly readjusted after the terrorist attack of $9 / 11$. Those countries that were counting on participation and membership in international organizations, such as Poland for example, also had to with time consider a more responsible approach to their own security, not only counting on international agreements, but prepare for a different sort of dangers. Today many dangers that a state has to face are called asymmetrical. This is not entirely new in history of military conflicts, but never did military strategist have to reconsider a whole array of actions to oppose the terrorist tactics against a different fields of state's operations - from political and economic to infrastructural, and many others.

Today a visibly lower number of armed or unarmed men, can do as much harm as in a past the entire armies. Therefore, the armed forces preparing to use new technologies have to become more specialized in order to counter the new dangers. This implies higher costs for the military in many areas of operations. Yet, the old dangers did not disappear entirely. In both cases it is the government that needs to properly manage the funds and prepare the readiness of the citizens able to defend its country on many levels of activity. Quiet possibly the reserve force is the more economical way in this predicament if they are well schooled and trained in contemporary technologies and way of war able to counteract asymmetrical dangers.

Many countries are moving away from creating big armies with large numbers of reservist, but in reality a force of many low qualified soldiers. Reorganization of such force seems to be of outmost importance for many states, including Poland. It is currently trying to reorganize its force and create a fully professional force of fewer but better trained men and women prepared for conflicts of the XXI century. This force is supposed to be more mobile and able to counteract to dangers on many levels of state, regional and international security. It is not supposed to show its capability just in the domestic affairs but also compatibility within international military cooperative organizations, such as NATO or inter-boarder cooperation between neighboring friendly countries. Its main goal is the competitiveness and ability to function in multidimensional environment ${ }^{4}$.

Professional armies are lower in numbers, since they can be better equipped and better trained, and at the same time can be more economical, as is stressed by politicians and some military personnel. Perhaps rightfully, since lower numbers mean lesser spending for the military infrastructure, weaponry, food and services, plus equipment and other necessities for functioning of the big army. Those who agree with such philosophy of change argue that new military force is more economical not only because of lowering number of enlisted personnel but especially because

4 See J.R. Deni, Alliance management and maintenance: restructuring NATO for the 21st century; Ashgate Publishing Company, Burlington 2007. 
Philosophical, some legal and political aspects of contemporary idea of reserve forces...

of creating new mechanisms of personnel exchange and different kind of training for new soldiers. With respect to this it is believed that some duties can be given to citizen able to hold arms in time of danger, but in peace performing other security functions, both in the army and in the civilian life.

Most surely the important aspect of that philosophy of change has to do with, not only better training, but especially with better education on matters dealing with state security. Main aspects of those training concentrate on diverse crisis situations, security management, mobility and responsiveness, health and safety, and others that border with the military issues and are not directly connected with typical military actions of the old type. This include also the administrative actions, education, transport and many other services, where the typical work is the same as that of the civilians, but in the military had to be performed until recently by the enlisted men and officers. Those changes must take time and they do not take place in an instance. Their main prerequisite is the legally issued direction given by politicians and acceptance of those changes through the legislative process. It is also a process that has to be symbiotic with changes in forces of other countries with which European countries like Poland cooperate.

When it comes to allied cooperation in NATO with respect to the reserves there is two major documents that regulate possible options: "NATO Framework Policy on Reserves" - MC441/1 and "NATO Force Structures" - MC317/1 in annex H, "Reserve Forces". The MC317/1 updated in July 2002 provided doctrinal guidance on changes in NATO structure first after the Cold War and it was doing away with old system of the Reaction Forces, Main Defense Forces and Augmentation Forces. It describes the model of education, combat readiness, and cooperation of allied military forces and presented in "annex H" propositions for the NATO members on design of the reserves. Based on the above there was the National Reserve Force Committee created in 1995 as the organization that is supposed to synthesize different countries' practices in respect to the reserves.

NATO document MC441/1 tries to define specificity of the reserve forces. Partial definition is given in point 1 of the document and states that the reserves are any "mobilisable" categories of personnel who are not normally employed on full-time military services. Such personnel may be "Voluntary, Ex-Regular or Conscript". The full definition is given in point 7 of this document: "The Reservist is any Service man or woman not normally on full-time service that may be called for temporary military activities". Said personnel is supposed to raise general capabilities of NATO forces. Created units can be assigned to "organized units or serve as individuals supporting Regular units"5.

5 MC 441/1 NATO Framework Policy on Reserves. 
Basic role of this document is to provide a policy guidance on possible use and contribution of reserve forces with respect to defense and other NATO missions, as a supporting role. There is at least two important points in that document that provides full conceptual paradigms for reserve force creation. When it discusses the strategic environment it states: "Alliance nations have considerably reduced their Regular forces and, in some cases, conscription has been, or is being, abolished or suspended. The general trend in NATO countries of reductions or Regular forces increases the relative importance of Reserve forces to NATO. As the importance of the contribution that Reservists make continues to grow within the Alliance, so does the requirement for NATO better to understand end exploit their inherent potential" 6 . It stresses out in point 6 of this document that while there are different national approaches to the reservists call up and training plus other issues, the new strategic concept based on NATO current missions points out to collective defense, conflict prevention and crisis management, as well as projection of stability.

It is the member nation's responsibility to prepare the reservists for its general duties at the appropriate NATO standards. As it is pointed out the members of the reserve forces should be able to present not only a military expertise but become a link between military and civilian communities. It is noted that "many reservists have useful specialized skills such as, but not limited to, medicine, engineering, logistics, law, expertise in foreign languages, public relations and information management systems". That expertise can work both ways, as is noted, since "at the same time, military service returns substantial benefits to the Reservist and the employer". Therefore, the training of the reservists can be beneficial to both sides, as is stressed out. Those benefits can be based on "considerable leadership, educational and training programs", as ideally predicts NATO Military Committee, and can be "directly transferable to their civilian environment". That civilian and military interaction is especially important in current political situations when the reservists are supposed participate in humanitarian and peace support operations.

The matters of reserve forces in NATO are not incidental but a part of larger scheme of development that we can observe since 1990s. As it is stated in the official documents, including the mentioned MC441/1, the importance of "NATO advisory and supporting organizations on reserve matters" is stressed by reference to MC248/1 in recognition of independent supporting organization such as Interallied Confederation of Reserve Officers (CIOR - French acronym of Confédération Interalliée des Officiers de Réserve), and second organization of the similar interests that acts recognized by NATO Committee under MC392 - National Reserve Forces Committee (NRFC). "The NRFC provides appropriate advice and support to CIOR to assist in its activities in support of Alliance goals and advises the MC in accordance with the current NATO

6 Op. cit., no. 5 
Philosophical, some legal and political aspects of contemporary idea of reserve forces...

protocol documents ${ }^{7}$. As it is stressed, the two organizations share a general attention in securing the excellence of the reserve forces. Both organizations work jointly, being officially acknowledged in the 1990 NATO Framework Policy on Reserves. Part of that cooperative process as an affiliated organization, of medical professionals, Confederation of Medical Reserve Officers from Allied Nations (CIOMR - French acronym for Confédération Interalliée des Officiers Medicaux de Réserve).

It is visible that philosophy of change presented by North Atlantic Military Committee is a part of a steady evolution that we can observe among in practice taken by number of member states. The significance of the reserve forces strengthening the regular conscripts is part of that evolution. The conceptualization of it was officially presented at the Washington NATO summit in April 1999 in Washington with new Strategic Concept accepted by member states. Although it is accepted by all members the time frame of implementation rests on individual capacity of practical solutions, that often are based on economic abilities of particular country, costs of new technology, employment issues, social factors, size of the country and its forces, along with other factors. Clearly, we cannot talk of unified routine in pragmatic sense with respect to forces adjustment.

If there is one common denominator however, that makes ongoing change possible, it is the acceptance of legal and political philosophy of a steady transformation, mainly referring to democratic and/or republican ideas, shared by the all NATO member states, as explained at the beginning of this article. How in practice that credo is positioned within political and military procedures and what are the realistic solutions executed by particular governments controlling its forces, is of course another question. From our point of view, there is at least two parts of that equation, one referring to practical abilities, the other to political solutions.

Looking at the first part, it has to do with numbers. The above position's main conceptual emphasis rests on the lower number of forces, but with higher mobility, training and effectively technologically advanced better fire power. This change applies both to the regulars and to the reserve forces throughout the alliance. The ratio number of the reserves to regulars may be a fraction of the regular forces or equal to it. We can expound this case on the following examples: in the United States, the numbers of regular conscripts and reserve forces are not far apart. Looking at the data from 2004, military active component was standing at about 1414000 soldiers, and reserve component at 875000 . No doubt in time of mobilization those numbers can easily go higher, thanks to the training and preparation of the individual ready reserve and inactive National Guard ${ }^{8}$. The same year in Great Britain the

MC 441/1 No. 18.

8 Capt. P. Harmand, Col. C.D. Rehberg, PH.D. USAFR, A Modern Reserve Component For The European Union In A Post-Cold War Era, ROA National Security Report, May 2004. 
active component in sheer numbers was standing at 210000 and 256700 reserves. In Germany it was 210400 active and 390 300. In France it was 260000 active and 50000 reserves (not counting about 50000 Gendarmerie). The ratio in other NATO countries also varied both in numbers of military and reserve individuals, based on country size and specificity of the forces.

By the same token, observing the time period of 5-7 years, above mentioned conceptual frame of change slowly materialized. In 2009 in Great Britain the number of regular forces was standing at 196000 , and 35000 of volunteer reserves, which can easily double to about 430000 if necessary. In Italy, Greece or Spain the reserves compose up to $40 \%$ of the regular conscripts numbers. In France, a more specific case, it is planned to raise the numbers of Operational Volunteer Reserves from 46500 in 2006 up to 94000 in 2012. In small countries like Lithuania the reserve forces consist of $30 \%$ of the regular forces ${ }^{9}$. Case of Lithuania presents a good example of positive evolution of the role of reserves in general military tactics and political involvement in external and internal duties of the soldiers. In domestic involvement their use can include military and no-military crisis situations, and in international mission they can become active professional soldiers.

In other countries there is also a tendency to lower the number of conscripts and reserves due to the reorganization process that is focusing on innovation and new military models. This example applies especially to Poland. It is still adjusting its strategic plans based on political and military alliances, and just like some other European countries had to go through many different stages of adaptations after the end of Cold War, being previously a member of the Warsaw Pact. Plans for refurbishing military structures in unison with basic NATO philosophy could not be the easiest and quick in implementation in this case. Many factors had to be considered and the choices were not easy, and quiet often economically costly. Implementing the change meant first of all lowering the number of conscripts, since the previous strategic conception had to be updated after Poland became a member of the alliance.

In the first decade of the XXI century the number of Poland's regular forces was numbering at about 150000 , and relative to it, there was approximately 240000 reservists. That status has changed since 2010. The Polish forces structure has been adapted accordingly with political and new military doctrine. Based on the new philosophy, it was decided that the regular forces will stand at 100000 of well trained, well equipped and very mobile troops. In addition, the modification of the armed forces called for 20000 reservists within National Reserve Service - that is a force of ready reservists ongoing a steady training within a specific period of time, from 2 up to 6 years. It doesn't of course include those possible forces that would have to be mobilized in case of a regular conflict. One can consider this equation as based

9 http://www.kam.lt/index.php/en/. 
Philosophical, some legal and political aspects of contemporary idea of reserve forces...

on political and economic solutions - being part of NATO and UE, as well as on plans of economic savings applicable because of the lower number of service man, and voluntary military contracts.

Currently the Polish armed forces are the smallest in its post II World War period. According to the data from the Ministry of National Defense their numbers stand at 99778 thousands, which is almost exactly the 100000 planned by the army reform system. Within those numbers we find 36501 regular conscripts, 36276 non-commissioned officers, 21555 commissioned officer at the rank lower than general, 2343 military students, and 120 generals ${ }^{10}$. This far-reaching reduction is based on the assessment needs for the armed forces presented by previous and the current government, based on the idea that Poland's political standing within different international alliances, including military ones, does not call for any bigger military force. The process of "professionalization of Polish Republic's military forces" is one of the priorities of polish government and is based on specific plans and time table. Its general aspects are important for the reserve forces. Even if created in 2010 National Reserve Force at the beginning of 2011 was falling short of its goal with only 3000 volunteers signed, those numbers will have to change to meet the 10000 optimally planned. Nonetheless, through democratic and economic incentives the changes will continue to best possible proportions.

The changes taking place in many NATO countries vary, but the philosophy of the change remains the same: lower numbers - better quality and citizen's readiness. They are based not just on previous long term policy but coincide also with some specific party politics, and particular government's ability to properly manage the military. There is of course other side to this military democratic process. Sometimes the military may become a part of unnecessary political pushing between different political parties, what may undermine its qualitative evolution. That struggle may have far reaching consequences. Yet, since the political processes are controlled by the Parliaments and democratically chosen members of the political establishment, specific solutions will be applied and anticipated problems, if they occur, should not be continuous but temporary. The politics of democracy and republican values acknowledge since ancient times the military and citizen soldier as one of the major force of its success. The global changes of contemporary world, wherever and whenever they occur as always have to do with politics, international relations, economic and technological evolutions, and the role of the military, as always, is to adapt.

10 Based on Poland's Ministry of Defense numbers published with a link to: http:/www.wp.mil.pl/pl/ strona/47/LG_54_55. 
BIBLIOGRAPHY

1. J.R. DenI, Alliance management and maintenance: restructuring NATO for the $21^{\text {st }}$ century, Ashgate Publishing Company, Burlington 2007.

2. P. Harmand, CAPT., C.D. Rehberg, Col., PH.D. USAFR, A Modern Reserve Component For The European Union In A Post-Cold War Era; ROA National Security Report, May 2004.

3. http://www.brittanica.com/EBchecked/topic/323910/Krumpersystem.

4. http://www.kam.lt/index.php/en/

5. H. KujAT, Gen., The Use of Reservists within NATO, Remarks by General Harald Kujat: http://www.nato.int/ims/2003/s030723e.htm.

6. NATO Documents: MC 441/1 NATO "Framework Policy on Reserves".

7. NATO DocUments: MC317/1, annex H, "Reserve Forces".

8. Poland's Ministry of Defense (link) http:/www.wp.mil.pl/pl/strona/47/LG_54_55.

9. B. Strauss, Reflections on the citizen-soldier, Parameters, U.S. War College, 2003.

Streszczenie. Starożytna idea żołnierza-obywatela jest wciąż obecna we współczesnych czasach. Dzisiaj w ramach procesów demokratycznych uzyskała nowy fundament, który został stworzony w obrębie ewolucji nowożytnych państw. Bazując na tym, autorska prezentacja przedstawia ogólny zarys podstawowych koncepcji tej ewolucji, w innym ujęciu niż historyczne. Jak stwierdza autor, siła i wielkość wojska związane są z filozofią państwa i zasadniczymi koncepcjami politycznymi, które ukierunkowują aspekty militarne w ramach demokratycznego państwa. Wpływa to zwłaszcza na ewolucję rozwoju sił wojskowych, równocześnie określając liczbę potencjalnych żołnierzy w systemie rezerw wojskowych. System ten zakorzeniony jest w natowskiej filozofii i koncepcji strategicznej, która zakłada wzmocnienie regularnych sił rezerwistami, występującymi w roli łącznika pomiędzy sferą społeczno-polityczną życia kraju a wojskiem. Taka koncepcja jest zgodna $\mathrm{z}$ nastawieniem wielu krajów międzynarodowej społeczności euroatlantyckiej, w tym Polski. Wspólny mianownik tego nastawienia zawiera się w idei republikańskiej demokracji i odpowiedzialności obywatela za swój naród. 